\title{
Pengaruh Perilaku Kepemimpinan dan Pengalaman Kerja Kepala Sekolah terhadap Motivasi Berprestasi Guru Agama Islam di SMA Negeri Kota Jambi
}

\author{
Hazizah $^{1 *} \&$ Mahmud $^{2}$ \\ Universitas Islam Negeri Sulthan Thaha Saifuddin, Jambi \\ *corresponding author: hazizah@gmail.com
}

\begin{abstract}
:
This research aims to determine and analyze; (1) description of the principal's leadership behavior and the teacher's work experience towards the motivation of the achievement of religious teachers; (2) influence of the principal's leadership behavior on the motivation of teacher achievement; (3) the relationship between the teacher's work experience and the motivation of the teacher's performance; (4) Influence of the principal's leadership behavior and teacher work experience on the motivation of the teacher's religious achievement. The study used descriptive analysis survey methods, with a sample of 35 religious teachers and used correlation and regression analysis. The results of the study found that the magnitude of the simultaneous influence between the principal's leadership behavior $\left(X_{1}\right)$ and the teacher's work experience $\left(X_{2}\right)$ on the teacher's achievement motivation (Y) was 0.746 which was classified as weak. Meanwhile, the simultaneous contribution of the variables $\left(X_{1}\right)$ and $\left(X_{2}\right)$ to $(Y)=R_{2}$ $x 100 \%$ or $0.7462 \times 100 \%=55.7 \%$ and the remaining $44.3 \%$ is determined by other variables. Then the rise and fall or the size of achievement motivation can be predicted through the regression equation: $=19.766+0.2213 \times 1+0.9734 \times 2$. The results of this study can be drawn several sub-conclusions as follows: (1) the magnitude of the influence of the principal's leadership behavior variable $\left(X_{1}\right)$ on teacher achievement motivation $(Y)$ is $0.606 \%$ while the contribution of the variable $\left(X_{1}\right)$ to $(Y)$ is $36.72 \%$. the remaining $63.28 \%$ is determined by other variables. (2) the magnitude of the influence of the teacher's work experience $\left(X_{2}\right)$ on the teacher's achievement motivation $(Y)$ is $0.746 \%$ while the contribution of the variable $\left(X_{2}\right)$ to $(Y)$ is $55.65 \%$ and the remaining $44.35 \%$ is determined by other variables. (3) the magnitude of the relationship between principal leadership behavior $\left(X_{1}\right)$ and teacher work experience $\left(X_{2}\right)$ is 0.609 then the contribution of variables $\left(X_{1}\right)$ and $\left(X_{2}\right)$ is $37.09 \%$ while the remaining $52.25 \%$.
\end{abstract}

KEYWORDS: Leadership behavior; motivation; teacher achievement; work experience.

Copyright @ Published by Program Studi Manajemen Pendidikan Islam Fakultas Tarbiyah dan Keguruan

Universitas Islam Negeri Sulthan Thaha Saifuddin jambi Mendalo Darat, Muaro Jambi, 36361, Indonesia 


\begin{abstract}
ABSTRAK:
Penelitian ini bertujuan untuk menentukan dan menganalisis; (1) deskripsi perilaku kepemimpinan kepala sekolah dan pengalaman kerja guru terhadap motivasi prestasi guru agama; (2) pengaruh perilaku kepemimpinan kepala sekolah terhadap motivasi prestasi guru; (3) hubungan antara pengalaman kerja guru dan motivasi prestasi guru; (4) pengaruh perilaku kepemimpinan kepala sekolah dan pengalaman kerja guru pada motivasi prestasi agama guru. Penelitian ini menggunakan metode survei analisis deskriptif, dengan sampel sebanyak 35 guru agama dan menggunakan analisis korelasi dan regresi. Hasil penelitian menemukan bahwa besarnya pengaruh simultan antara perilaku kepemimpinan kepala sekolah ( $\left.X_{1}\right)$ dan pengalaman kerja guru (X2) pada motivasi prestasi guru $(Y)$ adalah 0.746 yang tergolong lemah. Sementara itu, kontribusi simultan dari variabel $\left(X_{1}\right)$ dan $\left(X_{2}\right)$ ke $(Y)=R_{2} \times 100 \%$ atau $0.7462 \times 100 \%=55.7 \%$ dan $44,3 \%$ sisanya ditentukan oleh variabel lain. Kemudian naik turun atau ukuran motivasi pencapaian dapat diprediksi melalui persamaan regresi: $=19.766+0.2213 \times 1+0.9734 \times 2$. Hasil penelitian ini dapat ditarik beberapa sub-kesimpulan sebagai berikut: (1) besarnya pengaruh variabel perilaku kepemimpinan kepala sekolah (XI) pada motivasi prestasi guru (Y) adalah $0.606 \%$ sedangkan kontribusi variabel $\left(X_{1}\right)$ terhadap $(Y)$ adalah $36.72 \%$. Sisanya 63.28\% ditentukan oleh variabel lain. (2) besarnya pengaruh pengalaman kerja guru (X2) pada motivasi prestasi guru (Y) adalah $0.746 \%$ sedangkan kontribusi variabel (X2) terhadap (Y) adalah 55.65\% dan sisanya 44.35\% ditentukan oleh variabel lain. (3) besarnya hubungan antara perilaku kepemimpinan kepala sekolah (XI) dan pengalaman kerja guru (X2) adalah o.6o9 maka kontribusi variabel (X1) dan (X2) adalah 37.09\% sedangkan sisanya $52.25 \%$.
\end{abstract}

KATA KUNCI: Perilaku kepemimpinan; motivasi; prestasi guru; pengalaman kerja.

\title{
PENDAHULUAN
}

Pendidikan merupakan faktor utama dalam pembentukkan pribadi manusia. Pendidikan sangat berperan dalam membentuk baik atau buruknya pribadi manusia menurut ukuran normatif. Pemerintah telah berupaya menangani bidang pendidikan untuk memperoleh generasi penerus bangsa yang berkualitas dan mampu menyesuaikan diri untuk hidup bermasyarakat, berbangsa dan bernegara.

Reformasi pendidikan merupakan respon terhadap perkembangan tuntutan global sebagai suatu upaya untuk mengadaptasikan sistem pendidikan yang mampu mengembangkan sumber daya manusia untuk memenuhi tuntutan zaman yang sedang berkembang. Reformasi pendidikan dapat menjadi jaminan bagi perwujudan hak-hak azasi manusia untuk 
mengembangkan seluruh potensi dan prestasinya secara optimal guna kesejahteraan hidup di masa depan.

Sarana paling strategis bagi peningkatan kualitas daya manusia adalah pendidikan. Posisi pendidikan yang strategis dapat mengandung arti dan mencapai peningkatan kualitas sumber daya manusia apabila pendidikan tersebut memiliki sistem relevan dengan pembangunan dan kualitas yang tinggi baik dari segi proses maupun hasilnya. Sekolah menjadi lembaga pendidikan yang berfungsi memberikan pengetahuan, keterampilan dan membentuk sikap seseorang. Tinggi dan rendahnya mutu suatu sekolah tergantung pada pencapaian fungsi sekolah, semakin tinggi pencapaian suatu sekolah, maka semakin tinggi kualitas sekolah, sebaliknya semakin rendah pencapaian fungsi sekolah, maka semakin rendah pula kualitas sekolah. Tinggi dan rendahnya mutu sekolah akan berpengaruh pula terhadap perkembangan masyarakat.

Pendidikan memiliki arti yang sangat penting dalam pandangan Islam, karena Islam sangat menghargai dan menghormati seorang pendidik. Allah berfirman dalam surat Al- Mujaddalah ayat 11:

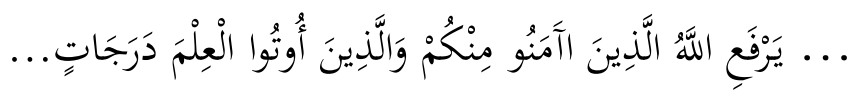

“... niscaya Allah akan tinggikan orang-orang yang beriman diantaramu dan orang-orang yang diberi ilmu pengetahuan beberapa derajat...” (Q.S. Al- Mujaddalah: 11)

Sekolah atau madrasah merupakan salah satu lembaga pendidikan untuk mencapai tujuan pembangunan nasional. Keberhasilan tujuan pendidikan di sekolah bergantung pada sumber daya manusia diantaranya kepala sekolah, guru, siswa, pegawai tata usaha, dan tenaga kependidikan lainnya. Dalam konteks pendidikan, kepala sekolah adalah seseorang yang mampu menggerakkan, mempengaruhi, memberikan motivasi dan mengarahkan orang-orang di dalam organisasi/lembaga pendidikan tertentu untuk mencapai tujuan yang telah dirumuskan. Kepala Sekolah adalah sumber daya yang diberi tugas dan wewenang khusus untuk memimpin lembaga pendidikan formal. Jabatan tertinggi dalam suatu lembaga pendidikan formal diberikan kepada kepala sekolah untuk menjadi pemimpin yang membawahi semua unsur personalia yang ada di sekolah tersebut. 
Menurut Sugandha, kepemimpinan merupakan proses mempengaruhi kegiatan kelompok yang terorganisasi dalam usaha menentukan tujuan dan mencapai (the Process of influenting the activities of an organized group in us effort toward goal setting and goal achievement). Dalam defenisi tersebut tercakup tiga unsur yang merupakan kondisi sosial dari leardership yaitu kelompok manusia, tujuan kelompok, dan deferensiasi tanggung jawab.

Kepala sekolah di lingkungan sekolah adalah orang yang bertanggung jawab atas terwujudnya semua kegiatan dalam koordinasi sebaik-baiknya. Kepala sekolah memiliki peran yang amat besar guna mewujudkan efektivitas output sumberdaya yang menjamin kesinambungan pembangunan bangsa. Seorang kepala sekolah harus memiliki kompetensi/pengalaman kerjanya yang mumpuni diiringi dengan perilaku teladan.

Setiap pemimpin pada dasarnya memiliki perilaku yang berbeda dalam memimpin para anggotanya. Pemimpin merupakan salah satu faktor yang dapat mempengaruhi berhasil tidaknya suatu organisasi sekolah. Dalam melaksanakan kepemimpinannya, pada umumnya kepala sekolah menjalankan dua fungsi, yaitu berkenan dengan tugas dan berkenaan dengan kelompok (bawahan). Seorang pemimpin yang mementingkan tugas atau hubungan rendah akan berperangai sebagai otoritarian dan cenderung untuk memerintah. Seorang pemimpin yang mementingkan tugas dan juga mementingkan hubungan, akan cenderung menawarkan gagasan-gagasannya. Seorang pemimpin yang mementingkan hubungan dan kurang mementingkan tugas akan cenderung berpartisipasi dengan kelompoknya. Seseorang yang kurang memperhatikan tugas maupun hubungan akan cenderung menyerahkan kewenangannya. Hersey dan Blanchard menjelaskan bahwa seorang pemimpin yang efektif akan mampu berperan sebagai pemberi perintah (teller), pemberi gagasan untuk dipilih oleh kelompok (seller), sebagai anggota kelompok (participator), dan sebagai utusan (delegator).

Fungsi lain yang harus diprioritaskan bagi seorang kepala adalah sebagai motivator yang memiliki strategi yang tepat untuk memberikan motivasi kepada para tenaga kependidikan dalam melakukan berbagai tugas dan fungsinya. Motivasi ini dapat ditumbuhkan melalui pengaturan lingkungan fisik, suasana kerja, disiplin, dorongan, penghargaan secara efektif dan penyediaan berbagai sumber belajar melalui perkembangan pusat sumber 
belajar. Motivasi yaitu suatu kekuatan/dorongan yang mengendalikan serta menggerakkan seseorang agar melakukan sebuah tindakan atau perilaku yang diarahkan dengan tujuan tertentu (Marwansyah dan Mukaram, 2002: 151).

Motivasi merupakan suatu kehendak atau keinginan yang muncul dalam diri seseorang yang menimbulkan semangat atau dorongan untuk bekerja secara optimal guna mencapai tujuan. Motivasi berasal dari kata dasar motif, yang mempunyai arti suatu perangsang, keinginan dan daya penggerak kemauan bekerja seseorang. Motivasi berkembang dengan taraf kesadaran seseorang akan tujuan yang hendak dicapainya. Berdasarkan dari penjelasan teori tersebut bahwa motivasi berprestasi tidak selalu timbul dengan sendirinya. Motivasi dapat ditimbulkan, dikembangkan, dan diperkuat oleh faktor-faktor lain. Seseorang yang mendapat motivasi yang pula usahanya untuk mencapai tujuan. Pengertian ini berarti pula bahwa motivasi dapat berubah.

Motivasi kerja merupakan kebutuhan pokok manusia dan sebagai insentif yang diharapkan memenuhi kebutuhan pokok yang diinginkan, sehingga keberadaan kebutuhan akan berakibat pada kesuksesan terhadap suatu kegiatan. Menurut Wibowo (2014), motivasi kerja adalah proses psikologis yang membangkitkan, mengarahkan dan ketekunan dalam melakukan tindakan secara sukarela yang diarahkan pada pencapaian tujuan. Dengan demikian motivasi kerja adalah gejala kejiwaan (psikologis) seseorang yang bersifat dinamis, menyejukan, dan spesifik untuk masing-masing guru. Apabila seseorang di dalam lingkungan kerjanya tidak dianggap/kurangnya perhatian oleh sesama rekan kerja maupun atasan, selalu didikte dan dikritik tanpa memberikan solusi, tidak pernah diberikan kesempatan ataupun reward dari hasil kerjanya, maka hal ini akan menimbulkan frustasi dan kurangnya rasa percaya diri. Keadaan ini akan menyebabkan seorang pegawai menjadi apatis, tidak bergairah, dan kehilangan kreativitas yang menimbulkan pemikiran yang menganggap dirinya tidak berguna, serta menghambat kelancaran proses manajemen di lingkungan kerjanya.

Motivasi merupakan kebutuhan untuk berprestasi yang merupakan refleksi dari dorongan dan tanggung jawab untuk kebutuhan akan pemecahan masalah. Kebutuhan merupakan fundamen yang mendasari perilaku pegawai. 
Pada dasarnya setiap orang dalam melaksanakan dan menyelesaikan tugasnya sehari-hari ingin selalu tampil prima, tepat, dan memperoleh hasil yang optimal dan berprestasi baik dibandingkan dengan yang lain. Ransanganransangan yang memungkinkan untuk meningkatkan prestasi kerja dilakukan secara optimal yang berbeda bagi setiap individu yang lazim disebut motivasi. Perilaku kepala sekolah juga dapat membangkitkan motivasi guru-guru atau sebaliknya dapat melemahkan motivasi guru.

Di kota Jambi, rendahnya pengalaman kerja guru masih ditemui di sekolah-sekolah. Fenomena ini dilihat dari kurangnya semangat para guru untuk mengikuti pelatihan-pelatihan, serta kurangnya interaksi antar guru dalam berbagi pengetahuan atau ide kreatif, khususnya pada guru di bidang mata pelajaran Pendidikan Agama Islam. Faktor ini dipengaruhi oleh kurangnya motivasi dalam diri dan kurangnya pengalaman kerja serta kurangnya loyalitas dari kepala sekolah dalam menunjang berbagai kegiatan sekolah. Motivasi kerja menjadi hal yang penting dilakukan untuk mengatasi hal tersebut.

\section{METODE}

Penelitian ini menggunakan metode survei dengan pendekatan deskriptif analisis. Data dikumpulkan melalui kuesioner, dengan data primer yang berasal dari hasil tabulasi data kuesioner dan informasi langsung yang diberikan dari pihak sekola SMA Negeri Kota Jambi sedangkan data sekunder berasal dari hasil laporan pencatatan-pencatatan dan dokumentasi lainnya.

Teknik analisis yang digunakan dalam penelitian ini adalah analisis data deskriptif dan inferensial. Analisis deskriptif digunakan dalam penyajian data, ukuran sentral, dan ukuran penyebaran penyajian data adalah daftar distribusi. Ukuran sentral adalah mean, median, dan modus. Peneliti menggunakan analisis korelasi dan regresi ganda.

\section{HASIL PENELITIAN DAN PEMBAHASAN}

Teknik analisis yang digunakan dalam penelitian ini adalah analisis korelasi dan regresi sederhana dan ganda. Hasil data deskriptif yaitu: median, mean, standar deviasi, varians dan penyajian data dalam bentuk distribusi untuk setiap variabel. 


\section{Pengujian Normalitas Data Baku}

Pada analisis regresi, persyaratan analisis yang dibutuhkan adalah bahwa alat regresi untuk setiap data variabel memiliki distribusi data yang normal. Hasil uji normalitas data variabel perilaku kepemimpinan kepala sekolah $\left(\mathrm{X}_{1}\right)$, pengalaman kerja $\left(\mathrm{X}_{2}\right)$, dan motivasi berprestasi guru agama Islam (Y) dapat dilihat pada table 1:

Table 1. Hasil Uji Normalitas Data Variabel X1, X2 dan Y

\begin{tabular}{ccccccc}
\hline & \multicolumn{3}{c}{ Kolmogorov-Smirnov } & \multicolumn{3}{c}{ Shapiro-Wilk } \\
\cline { 2 - 7 } & Statistic & df & Sig. & Statistic & df & Sig. \\
\hline $\mathrm{X}_{1}$ & 0.077 & 35 & 0.200 & 0.962 & 35 & 0.256 \\
$\mathrm{X}_{2}$ & 0.107 & 35 & 0.200 & 0.976 & 35 & 0.634 \\
$\mathrm{Y}$ & 0.121 & 35 & 0.200 & 0.974 & 35 & 0.576 \\
\hline
\end{tabular}

Tabel 1. menunjukkan bahwa pengujian dengan uji KolmogoroVSmirnov diperoleh hasil signifikan pada masing-masing variabel yaitu sebesar o.20o. Ketiga variabel tersebut terbukti berdistribusi normal karena memiliki tingkat sig. $\geqslant 0.05$.

\section{Pengujian Homogenitas}

Pada analisis regresi, persyaratan analisis yang dibutuhkan adalah bahwa regresi untuk setiap pengelompokkan berdasarkan variabel terikatnya memiliki variansi yang sama. Hasil uji homogenitas data variabel $\mathrm{X}_{1}, \mathrm{X}_{2}$ dan $\mathrm{Y}$ dapat dilihat pada tabel 2:

Table 2. Hasil Uji Homogenitas Data Variabel X1, X2 dan Y

\begin{tabular}{cccccc}
\hline & & $\begin{array}{c}\text { Levene } \\
\text { Statistic }\end{array}$ & $\mathbf{d f}^{\mathbf{1}}$ & $\mathbf{d f}^{\mathbf{2}}$ & Sig. \\
\hline & Based om Mean & 0.101 & 2 & 102 & 0.904 \\
Data & Based on Median & 0.097 & 2 & 102 & 0.908 \\
Baku & $\begin{array}{c}\text { Based on Median and with } \\
\text { adjusted df }\end{array}$ & 0.097 & 2 & 100.970 & 0.908 \\
& Based on trimmed mean & 0.099 & 2 & 102 & 0.906 \\
\hline
\end{tabular}

Tabel 2. menunjukkan hasil homogenitas dari pengujian statistic based on mean dengan signifikansi 0.904 yang melebihi 0.05 atau sig. $\geqslant 0.05$. 


\section{Pengujian Linieritas Regresis}

Pada analisis regresi, persyaratan analisis yang dibutuhkan adalah bahwa alat regresi untuk setiap data variabel memiliki model regresi linier. Hasil uji linieritas data variabel $\mathrm{X}_{1}, \mathrm{X}_{2}$ dan $\mathrm{Y}$ dapat dilihat pada Tabel 3 dan Tabel 4:

Tabel 3. Hasil Uji Linieritas Data Variabel Xı dan Y

\begin{tabular}{|c|c|c|c|c|c|c|c|}
\hline & & & $\begin{array}{c}\text { Sum of } \\
\text { Squares }\end{array}$ & df & $\begin{array}{c}\text { Mean } \\
\text { Square } \\
\end{array}$ & $\mathbf{F}$ & Sig. \\
\hline \multirow{4}{*}{$\mathrm{Y}^{*} \mathrm{X}_{1}$} & \multirow{3}{*}{$\begin{array}{l}\text { Between } \\
\text { Groups }\end{array}$} & Combined & 3064.905 & 27 & 113.515 & $5 \cdot 531$ & 0.013 \\
\hline & & Linierity & 1678.160 & 1 & 1678.160 & 81.766 & 0.000 \\
\hline & & $\begin{array}{l}\text { Deviation from } \\
\text { linierity }\end{array}$ & 1386.745 & 26 & 53.336 & 2.599 & 0.097 \\
\hline & \multicolumn{2}{|c|}{$\begin{array}{l}\text { Within Groups } \\
\text { total }\end{array}$} & $\begin{array}{c}143.667 \\
3208.571\end{array}$ & $\begin{array}{c}7 \\
34\end{array}$ & 20.524 & & \\
\hline
\end{tabular}

Tabel 3. menunjukkan bahwa pengujian yang dilakukan dengan uji linieritas memiliki regresi linier dengan signifikansi untuk variabel terikat (Y) terhadap variabel bebas (X1) yaitu sebesar 2.559 yang melebihi tingkat signifikansi yang ditetapkan yaitu 0.05 atau sig. $\geqslant 0.05$.

Tabel 4. Hasil Uji Linieritas Data Variabel X2 dan Y

\begin{tabular}{|c|c|c|c|c|c|c|c|}
\hline & & & $\begin{array}{l}\text { Sum of } \\
\text { Squares }\end{array}$ & df & $\begin{array}{c}\text { Mean } \\
\text { Square }\end{array}$ & $\mathbf{F}$ & Sig. \\
\hline \multirow{4}{*}{$\mathrm{Y}^{*} \mathrm{X}_{1}$} & \multirow{3}{*}{$\begin{array}{l}\text { Between } \\
\text { Groups }\end{array}$} & Combined & 2916.905 & 26 & 112.189 & 3.077 & 0.051 \\
\hline & & Linierity & 1503.554 & 1 & 1503.554 & 41.240 & 0.000 \\
\hline & & $\begin{array}{l}\text { Deviation from } \\
\text { linierity }\end{array}$ & 1413.350 & 25 & 56.6534 & 1.551 & 0.267 \\
\hline & \multicolumn{2}{|c|}{$\begin{array}{l}\text { Within Groups } \\
\text { total }\end{array}$} & $\begin{array}{r}143.667 \\
3208.571\end{array}$ & $\begin{array}{l}291.887 \\
320.571\end{array}$ & 12 & $\begin{array}{c}8 \\
34\end{array}$ & 36.458 \\
\hline
\end{tabular}

Tabel 4. menunjukkan bahwa pengujian yang dilakukan dengan uji linieritas juga menunjukkan regresi linier dengan hasil signifikansi untuk variabel terikat $(\mathrm{Y})$ terhadap variabel bebas $\left(\mathrm{X}_{2}\right)$ yaitu sebesar 1.551 yang melebihi tingkat signifikansi yang ditetapkan yaitu 0.05 atau sig. $\geqslant 0.05$.

Berdasarkan serangkaian pengujian terhadap hipotesis dengan menggunakan teknik analisis statistik yang sudah ditentukan semula, yaitu analisis korelasi, regresi baik sederhana maupun berganda. Hasil perhitungan dari program SPSS 21, dengan menggunakan data yang sudah dibakukan 
(dinaikkan dari data ordinal menjadi data interval), diperoleh hasil sebagai berikut:

Tabel 5. Analisis Korelasi, Regresi Sederhana dan Regresi Berganda pada

\begin{tabular}{ccccc}
\multicolumn{5}{c}{ variabel X1, X2, dan $\mathbf{~}$} \\
\hline Variabel & & $\mathbf{X}_{\mathbf{1}}$ & $\mathbf{X}_{\mathbf{2}}$ & $\mathbf{Y}$ \\
\hline t-hitung & $\mathrm{X}_{1}$ & - & 5.583 & 6.015 \\
& $\mathrm{X}_{2}$ & 5.583 & - & 5.395 \\
Pearson & $\mathrm{Y}$ & 6.015 & 5.395 & - \\
Correlation & $\mathrm{X}_{1}$ & 1.000 & 0.697 & 0.723 \\
& $\mathrm{X}_{2}$ & 0.697 & 1.000 & 0.685 \\
\multirow{2}{*}{ Signifikansi } & $\mathrm{Y}$ & 0.723 & 0.685 & 1.000 \\
& $\mathrm{X}_{1}$ & - & 0.000 & 0.000 \\
& $\mathrm{X}_{2}$ & 0.000 & - & 0.000 \\
& $\mathrm{Y}$ & 0.000 & 0.000 & - \\
\hline
\end{tabular}

Tabel 5 menunjukkan korelasi antar variabel penelitian yang dapat dinarasikan sebagai berikut:

a. Analisis Pengaruh $\left(\mathrm{X}_{1}\right)$ terhadap $(\mathrm{Y})$

Dari hasil analisis korelasi antara variabel $\mathrm{X}_{1}$ terhadap $\mathrm{Y}$ diperoleh nilai t-hitung $=6,015$. Jika t-hitung $\geqslant t$-tabel, maka korelasi $\mathrm{X}$ terhadap $\mathrm{Y}$ adalah signifikan. Berdasarkan hasil perhitungan pada Tabel di atas, dengan ketentuan $\alpha=0.05, \mathrm{dk}=\mathrm{N}-2=35-2=33$ sehingga didapat $\mathrm{t}-$ tabel $=1.697$ dimana $\mathrm{t}$-hitung $\geqslant \mathrm{t}$-tabel atau $6.015 \geqslant 1.697$ maka kedua variabel berkorelasi signifikan, artinya terdapat pengaruh antara perilaku kepemimpinan kepala sekolah ( $\left.\mathrm{X}_{\mathrm{l}}\right)$ terhadap motivasi berprestasi guru agama Islam (Y) secara sugnifikan.

b. Analisis Pengaruh ( $\left.\mathrm{X}_{2}\right)$ terhadap $(\mathrm{Y})$

Dari hasil analisis korelasi antara variabel $\mathrm{X} 2$ terhadap $\mathrm{Y}$ diperoleh nilai $t$-hitung $=5.395$. Jika $t$-hitung $\geqslant t$-tabel, maka korelasi $\mathrm{X}_{2}$ terhadap $\mathrm{Y}$ adalah signifikan. Berdasarkan hasil perhitungan pada Tabel di atas, dengan ketentuan $a=0.05, \mathrm{dk}=\mathrm{N}-2=35-2=33$ sehingga didapat $\mathrm{t}-$ tabel $=1.697$ dimana $\mathrm{t}$-hitung $\geqslant \mathrm{t}$-tabel atau $5.395 \geqslant 1.697$ maka kedua variabel berkorelasi signifikan, artinya terdapat pengaruh antara pengalaman kerja $\left(\mathrm{X}_{2}\right)$ terhadap motivasi berprestasi guru agama Islam (Y) secara signifikan. 
c. Analisis Korelasi (X1) dengan (X2)

Dari hasil analisis korelasi antara variabel $\mathrm{X}_{\mathbf{1}}$ dengan $\mathrm{X}_{\mathbf{2}}$ diperoleh nilai t-hitung $=5.583$. Jika t-hitung $\geqslant \mathrm{t}$-tabel, maka korelasi $\mathrm{X}_{1}$ dengan $\mathrm{X}_{2}$ adalah signifikan. Berdasarkan hasil perhitungan pada Tabel di atas, dengan ketentuan $\alpha=0.05, \mathrm{dk}=\mathrm{N}-2=35-2=33$ sehingga didapat $\mathrm{t}-$ tabel $=1.697$ dimana $\mathrm{t}$-hitung $\geqslant \mathrm{t}$-tabel atau $5.583 \geqslant 1.697$ maka kedua variabel berkorelasi signifikan, artinya terdapat hubungan antara perilaku kepemimpinan kepala sekolah $\left(\mathrm{X}_{\mathbf{1}}\right)$ dengan pengalaman kerja guru agama islam (X2) secara signifikan.

d. Analisis Regresi Berganda untuk (X1), (X2) terhadap (Y)

Hasil perhitungan secara simultan antara variabel $\mathrm{X}_{1}$ dan $\mathrm{X}_{2}$ terhadap Y dapat dilihat pada Tabel 6:

Tabel 6. Analisis Regresi Berganda pada Variabel X1 dan X2 terhadap Y

\begin{tabular}{cccccc}
\hline $\mathbf{R}$ & $\mathbf{R}$ Square & $\mathbf{F}$ & $\mathbf{d f}^{\mathbf{1}}$ & $\mathbf{d f}^{\mathbf{2}}$ & Signifikansi $\mathbf{F}$ \\
\hline 0,783 & 0,614 & 25,428 & 2 & 32 & 0,00 \\
\hline
\end{tabular}

Berdasarkan Tabel 21 di atas menunjukkan bahwa terdapatnya pengaruh secara simultan pada semua variabel secara signifikan.Dimana R2 x 100\% atau $0.7662 \times 100 \%=58.68 \%$ (o.5868) sedangkan sisanya $41.32 \%$ ditentukan oleh variabel lain. Untuk tingkat signifikansi korelasi ganda pada variabel $X_{1}$ dan $X_{2}$ terhadap Y diperoleh nilai F sebesar 22.684, jika F-hitung $\geqslant$ F-tabel berarti signifikan sehingga hasil yang diperoleh menunjukkan F-hitung $\geqslant$ F-tabel atau 22.684 $\geqslant 3.300$ artinya secara simultan terdapat pengaruh yang signifikan antara variabel perilaku kepemimpinan $\left(\mathrm{X}_{1}\right)$ dan pengalaman kerja kepala sekolah $\left(\mathrm{X}_{2}\right)$ terhadap motivasi berprestasi guru agama Islam (Y).

\section{Pengaruh Perilaku Kepemimpinan Kepala Sekolah terhadap Motivasi Berprestasi Guru Agama Islam}

Perilaku kepemimpinan kepala sekolah berpengaruh kuat dan signifikan terhadap motivasi berprestasi guru agama Islam di SMA Negeri Kota Jambi. Hal ini sesuai dengan yang diungkapkan oleh Assad bahwa perilaku kepemimpinan merupakan suatu proses untuk mencapai tujuan organisasi yang dapat mendorong, menuntun, mengajak, dan menggerakkan orang lain. Berdasarkan hasil penelitian diperoleh kesimpulan bahwa tinggi dan kuatnya 
perilaku kepemimpinan kepala sekolah akan lebih meningkatkan motivasi berprestasi pada guru agama Islam pada SMA Negeri kota Jambi.

\section{Pengaruh Pengalaman Kerja terhadap Motivasi Berprestasi Guru Agama Islam}

Pengalaman kerja berpengaruh kuat dan signifikan terhadap motivasi berprestasi guru agama Islam di SMA Negeri Kota Jambi dipengaruhi adanya dorongan atau motivasi dari guru itu sendiri. Pengalaman mengajar adalah lamanya guru mengajar suatu pelajaran (Suyitno, 2012). Seorang guru yang memiliki pengalaman mengajar akan lebih mudah dalam melaksanakan kegiatan belajar mengajar yang berkualitas.

\section{Hubungan Perilaku Kepemimpinan Kepala Sekolah dengan Pengalaman Kerja}

Perilaku kepemimpinan memiliki hubungan yang kuat dengan pengalaman kerja. Hal ini terbukti dari nilai koefisien korelasi sebesar 0.697 yang menunjukkan adanya hubungan kuat yang dimiliki kedua variabel tersebut. Hasil penelitian ini sependapat dengan hasil penelitian yang dilakukan oleh Maddepunggeng, dkk (2016), yang menjelaskan bahwa pengalaman kerja yang dimiliki pekerja serta gaya kepemimpinan yang baik dari seorang pemimpin dapat meningkatkan kinerja SDM di perusahaan/ proyek yang penulis tinjau.

Gaya kepemimpinan adalah perilaku yang digunakan oleh seseorang pada saat orang tersebut mencoba mempengaruhi orang lain (Miftah Toha, 1993: 297). Hal ini menunjukkan bahwa adanya hubungan antara perilaku kepemimpinan dengan pengalaman kerja yang dimiliki, dapat berpengaruh secara langsung pada standar pekerjaannya serta meningkatkan prestasi sumber daya manusia.

Pengaruh Perilaku Kepemimpinan dan Pengalaman Kerja Kepala Sekolah Secara Simultan terhadap Motivasi Berprestasi Guru Agama Islam

Perilaku kepemimpinan dan pengalaman kerja kepala sekolah berpengaruh secara simultan terhadap motivasi berprestasi guru agama Islam di SMA Kota Jambi. Hal ini ditunjukkan dari hasil uji regresi berganda yang diperoleh persamaan regresi $\mathrm{Y}=8.518+0.479 \mathrm{X}_{1}+0.351 \mathrm{X}_{2}$, artinya konstanta 
sebesar 8.518 dapat menjelaskan jika tidak ada kenaikan nilai dari variabel perilaku kepemimpinan kepala sekolah $\left(\mathrm{X}_{1}\right)$ dan pengalaman kerja $\left(\mathrm{X}_{2}\right)$, maka nilai motivasi berprestasi guru agama Islam di SMA Negeri Kota Jambi (Y) adalah 8.518. Koefisien regresi sebesar 0.479 menunjukkan bahwa setiap peningkatan (karena tanda positif) satu skor atau nilai Xı akan memberikan kontribusi sebesar 0.479 dan koefisien regresi sebesar 0,351 menunjukkan bahwa setiap peningkatan (karena tanda positif) satu skor atau nilai X2 akan memberikan kontribusi sebesar 0.351. Perilaku kepemimpinan adalah proses mempengaruhi orang lain ke arah tujuan organisasi sedangkan motivasi (Tika, 2006). Motivasi tersebut terbentuk dari sikap (attitude) seseorang dalam menghadapi situasi kerja (situation) (Mangkunegara, 2005). Motivasi merupakan kondisi atau energi yang menggerakkan diri seseorang yang terarah atau tertuju untuk mencapai tujuan organisasi perusahaan. Pengalaman kerja akan menjadi penunjang diri baik dalam pengetahuan, keterampilan maupun kemampuan yang dimiliki seseorang untuk mengemban tanggung jawab dari pekerjaan sebelumnya (Wariati, 2015).

\section{SIMPULAN}

Hasil perhitungan skor perilaku kepemimpinan diperoleh $\mathrm{X}_{1}=43.83$ untuk perilaku kepemimpinan inisiasi dan $\mathrm{X}_{2}=65.11$ untuk konsiderasi yang menunjukkan adanya kecenderungan perilaku konsiderasi kepemimpinan kepala sekolah di SMA Negeri Kota Jambi. Besarnya pengaruh antara variabel perilaku kepemimpinan kepala sekolah (X1) terhadap motivasi berprestasi guru agama Islam (Y), yang dihitung dengan koefisien korelasi adalah 0.723 atau rxIy $=0.723$. Besarnya pengaruh antara variabel pengalaman kerja (X2) terhadap motivasi berprestasi guru agama Islam (Y) yang dihitung dengan koefisien korelasi adalah 0.685 atau rxly $=0.685$. Besarnya pengaruh antara variabel perilaku kepemimpinan kepala sekolah $\left(\mathrm{X}_{1}\right)$ dengan pengalaman kerja (X2) yang dihitung dengan koefisien korelasi adalah 0.697 atau rxIy $=0.697$. Besarnya pengaruh secara simultan antara perilaku kepmimpinan dan pengalaman kerja kepala sekolah terhadap motivasi berprestasi guru agama islam ditunjukkan dengan nilai koefisien R-Square sebesar 0.586 (merupakan pengkuadratan dari koefisien korelasi sebesar 0.766 atau 0.7662 ) dan 0.685 dengan persamaan regresi $\mathrm{Y}=8.518+0.479 \mathrm{X}_{1}+0.35 \mathrm{X}_{2}$. Hal ini menunjukkan hubungan antara perilaku kepemimpinan dapat berpengaruh positif kepada 
bawahan tergantung dari pengalaman kerja yang dimiliki sebagai penunjang diri baik soft skill maupun hard skill sehingga tugas dan tanggung jawab dapat diemban dengan baik, dan membentuk keinginan atau kesadaran dalam diri termotivasi untuk berprestasi sesuai dengan visi dan misi sebagai seorang pendidik.

\section{REFERENSI}

Burhanuddin. (1994). Analisis Administrasi Manajemen dan Kepemimpinan Pendidikan. Jakarta: Bumi Aksara.

C.N.Coefer. (1964). Motivation. New York: John Willey an Sons.

Dirawat, dkk. (1970). Pengantar Kepemimpinan Pendidikan. Surabaya: Usaha Nasional.

Gomes, FC. (1997). Manajemen Sumber Daya Manusia. Yogyakarta: Andi Offset.

Hikmat. (2011). Manajemen Pendidikan. Bandung: Pustaka Setia.

Hersey, P. tt. Management of Organization Behavior. Englewood Cliffs, N. J: Prentice- Hall.Inc.

Ivancevich, J. M. (2007). Human Resource Management. New York: McGraw Hill.

Kartono, Kartini. (2003). Gaya Kepemimpinan. Widiya Karya: Jakarta.

Krames, Jeffrey A. (2002). The Jack Welch Lexicon of Leadership. Yogyakarta: Andi Yogyakarta.

Majjamal al-malik fali thib'at. (1418). Al-Quran dan Tarjamah. Madinah: Saudia Arabia, 1418.

Mujiono. (2002). Manajemen dan Kepemimpinan. Jakarta: Karya Cipta.

Moslow, A. H. (1971). Motivation and Personality. New York: Paper anf Row Publisher.

Maddepunggeng, Andi, dkk. (2016). "Pengaruh Pengalaman Kerja dan Gaya Kepemimpinan terhadap Kinerja Sumber Daya Manusia (SDM) Konstruksi." Jurnal Konstruksia, 8(1).

Nawawi, Hadari. (1988). Administrasi Pendidikan. Jakarta: CV. Haji Masagung. Sardiman, A. M. (1996). Interaksi dan Motivasi Mengajar. Jakarta: Rajawali.

Siagian. (1992). Fungsi-Fungsi Manajemen. Jakarta: Bumi Aksara.

Stoner, JAF. (1989), Manajemen, terj., Alfanso Sirait. Jakarta: Erlangga.

Sugiono. (2003). Statistik untuk Penelitian. Bandung: Alfabet.

Sutarto. (1989). Dasar-Dasar Kepemimpinan Administrasi. Yogyakarta:

Gajahmada University Press.

Syah. (1999). Psikologi Pendidikan dan Pendekatan Baru. Bandung: PT. Remaja Rosdakarya. 
Sambas, Ali Muhiddin dan Maman Abdurrahman. (2009). Analisis Korelasi, Regresi dan Jalur. Jakarta.

Tika \& H. Moh Pabendu. (2006). Budaya Oerganisasi dan Peningkatan Kinerja Perusahaan. Jakarta: PT Bumi Aksara.

Wijono. (1989). Administrasi dan Survevisi Pendidikan. Jakarta: Dirjen P2LPTK. Wariati, Nana, dkk. (2015). "Pengaruh Disiplin Kerja dan Pengalaman Kerja Terhadap Kinerja Pegawai Dinas Pendapatan Pengelolaan Keuangan dan Aset Kabupaten Barito Timur." Jurnal Wawasan Manajemen, 3(3).

Yamin, Martinis. (2011). Paradigma baru Pembelajaran. Jakarta: Gaung Persada Press. 